\title{
Evaluating the Impacts of Online Banking Factors on
}

\section{Motivating the Process of E-banking}

\author{
Akram Jalal \\ Management Information System Department, College of Business and Finance, Ahlia University \\ P.O. box 10878, 1st Floor Gosi Complex Exhibitions Road, Manama, Kingdom of Bahrain \\ Tel: 00973-3838-3411_E-mail: ajalal@ahliauniversity.edu.bh \\ Jassim Marzooq \\ College of Business and Finance, Ahlia University \\ P.O. box 10878, 1st Floor Gosi Complex Ex hibitions Road, Manama, Kingdom of Bahrain \\ Hassan A. Nabi \\ College of Business and Finance, Ahlia University \\ P.O. box 10878, 1st Floor Gosi Complex Exhibiti ons Road, Manama, Kingdom of Bahrain
}

Received: March 5, $2011 \quad$ Accepted: April 2, $2011 \quad$ doi:10.5539/jms.v1n1p32

\begin{abstract}
Purpose - The purpose of this research paper is to explore and mature the Impact of selected factors on the customers' intention to use internet banking in Bahrain.

Design/methodology/approach - This research based on an empirical study using a questionnaire with five-point Likert-scale, is applied to 171 usable responses. Three factors are tested, that is perceived usefulness (PU), perceived ease of use (PEOU), security and privacy (PC).

Findings - Results indicate that all the elements for the three identified factors are important with respect to the users' adoption of e-banking services. Credibility factors (Security and Privacy) are the major sources of dissatisfaction, which have remarkably impacted users' satisfaction. In the meantime, perceived ease of use (PEOU) and perceived usefulness (PU) are sources of satisfaction. The results also disclose that security and privacy factors play an important part in determining the users' acceptance of e-banking services with respect to different segmentation of age group, income level and level of education.
\end{abstract}

Keywords: Online Banking, E-banking, Banking service

\section{Introduction}

In the era of globalization and with the increasing competition in all the fields around the world many companies have modified their strategies so they can reach their customers around the world easier and cheaper. However the rapid growth of systems that rely on electronic technology - especially those relating to the Internet and personal computer - led to a significant change in the exchanging of products and services.

Many Service organizations have adopted modern technology to reduce costs and enhance customer service quality, delivery, and standardize core service offerings. In addition a lot of non-banking companies entered the banking industry by offering products and financial services, giving the customers a lot of options and alternatives to carry out their banking transactions, this difficulty of the business process in the financial sector forces the banks to develop an alternative technological channel to attract customers and improve their perception.

The rapid technological diffusion makes the internet the best way to provide customers with banking services regardless of the limits of time and geography. And that's what makes banks consider the internet as an important part of their strategic plans. 
Internet technology has changed the design and the way of delivering the financial services and as a result the banking industry has made continuous innovations - especially in the field of communications and information technology - that ultimately led to the emergence of the idea of what is known as the "online banking".

Banking services through the internet is a way to keep the existing customers and attract others to the bank, In this paper we define online banking as "an internet portal, through which customers can use different kinds of banking services ranging from bill payment to making investments" (Pikkarainen et al., 2004).

Compared to the traditional approach, online banking is an inexpensive straightforward way to conduct banking business, exchange of personalized information and buying and selling goods and services from any place at any time.

Despite the many benefits provided by this service to the bank and its customers, it remains a double-edged sword and not used by every customer, because the increasing distance between the bank and customers may lead to lack of confidence and an increasing in security concerns. As a result, the quality of electronic banking services become an important area of attention among the researchers and banks managers due to its strong influence on the business performance, lower costs, customer satisfaction, customer loyalty, and profitability (Seth et al., 2004).

The main objective of this study is to focus on the importance of understanding the customer's perception about internet banking by investigating and measuring the impact of selected factors such as perceived usefulness (PU), perceived ease of use (PEOU), security and privacy (PC) and how they can influence the customer acceptance to conduct banking transactions via the internet, based on the empirical data collected from individual customers in Bahrain.

In the next section we will give some background information about the internet banking sector and review the relevant literature in this area, the following section describes the research methodology, which is then followed by the data analysis and the results from the survey. The paper concludes with a discussion, outlining the implications of the findings and the limitations of the study.

\section{Literature review}

TAM is one of the most important literatures in the field of customer acceptance of the modern technology applications and it will be discussed briefly.

\subsection{Technology acceptance model (TAM)}

The technology acceptance model (TAM) was developed by Davis (1989) and Davis et al. (1989) to explain the acceptance of information technology; it may be used to predict online banking adoption. (TAM) is a perfect model which shows how users accept and use a technology.

\section{[Insert figure 1 here]}

The TAM found that the user adoption of a new technology is determined by his intention to use it; the main determinants of user's acceptance are the two beliefs (perceived usefulness (PU) and perceived ease of use (PEOU)) which will be defined in the frame work of this research.

As can be seen that the TAM gives an idea about the factors that affect the customer intention to use new technology, the TAM concepts in predicting customers' intention of adoption of IB were supported by several new studies, such that of (Chen and Barnes 2007; T.C. Edwin Cheng et al. 2006) which found that (PEOU), (PU) and security and privacy affect customer adaptation intentions.

The credibility factors were also discussed by Qureshi et al., (2008) who study the e-banking in a specific manner and claimed that (PU), security and privacy are the main perusing factors to accept online banking system. Which is smellier to the findings of Celik (2008) who study the same factors and finally stated that (PU) and (PEOU) are direct determinants of customers' attitudes towards using internet banking.

In addition, Moutaz Abou-Robieh (2005) studied the relationship between respondents' comfort level, feeling of security and their attitudes towards e-banking; he found that there is a correlation between these factors with regard to the customers' age, annual salary, and level of education. This correlation was also noticed by other researchers such as Alda's-Manzano et al. (2009) who focused on the credibility variables and conclude that "TAM beliefs and perceived risks (security, privacy, performance and social) have a direct influence on e-banking adoption", in other word he considered Trust as a key variable that reduces perceived risk.

Furthermore, Wai-Ching Poon (2008) identified ten significant factors related to the users' adoption of e-banking services. Security and Privacy were the major sources of dissatisfaction, play an important role in determining 
the users' acceptance of e-banking services with respect to different segmentation of age group, education level and income level. The other factors such as accessibility, convenience, design and content were sources of satisfaction.

During the last ten years many research papers study a large number of factors affecting the customer intention to use internet banking, it's impossible to discuss all of them in few pages especially because most of them do not fit the Bahraini case, some of these studies:

Chen, Y. H. and Barnes, S. (2007) pointed out that "(PU), perceived security, perceived privacy, perceived good reputation, and willingness to customize are the important antecedents to online initial trust." It is also discovered that both online initial trust and familiarity with online purchasing have a positive impact on purchase intention.

Riyadh et al. (2009) stated that "Seven variables affecting e-banking adoption by SMEs are identified. They are: organizational capabilities, perceived benefits, perceived credibility (PC), perceived regulatory support, ICT industries readiness, lack of financial institutions readiness and institutional influence."

In addition to the important impact of education, trust and resistance to change on the attitude towards the likelihood of adopting online banking, Al-Somali et al. (2009) studied the effects of other factors such as the quality of the internet connection, the awareness of online banking and its benefits, the social influence and computer self-efficiency. He found that they have significant effects on (PU) and (PEOU) of online banking acceptance.

Aderonke and Charles (2010) found that 'Banks' customers who are active users of e-Banking system use it because it is convenient, easy to use, time saving and appropriate for their transaction needs. Also the network security and the security of the system in terms of privacy are the major concerns of the users and constitute hindrance to intending users."

Sadeghi and Hanzaee (2010) perform a model with the following seven factors: convenience, accessibility, accuracy, security, usefulness, bank image and web site design. And considered them as the main determinants of customer's quality perception in e-banking services. Finally Yap, K et al. (2010) who concentrate on the Traditional service quality and website features and their influence on building consumers trust in e-banking.

This research paper will focus on three factors (PU, PEOU and PC) affecting the user's intention to use e-banking, this factors were chosen according to their share of researchers' attention, so it's important to list some of literatures that specifically discuss those factors.

Hanudin Amin. (2007) found that the previous factors had a significant relationship with behavioral intention; these measures are good determinant for undergraduate acceptance for internet banking. The Results also suggest that PU and PEOU had a significant relationship with computer self-efficacy. Padachi et al. (2007) almost get the same conclusion but he also discuss how important are other factors such as the cost of computers, internet accessibility, and convenience of use. Similarly Z Liao and WK Wong (2008) study the same three factors (PU, PEOU and PC) and observed that they significantly influence customer interactions with Internet e-banking and that the individuals would place a great emphasis on the security of Internet-based financial transactions.

Jahangir N. and Begum N. (2008) and Safeena et al. (2009) agreed that the considered factors (PU, PEOU and PC) are the important determinants of online banking adoption, have a strong and positive effect on customers to accept online banking system.

\section{Methodology}

To assess the factors influencing the intention to use internet banking in Bahrain, a survey was conducted during the last quarter of year 2010. A Questionnaire were designed and distributed to retail users of banking services of different age group and of different educational level attained across the island.

\subsection{Survey instrument}

The questionnaire we prepared for this exercise was divided into 2 sections. The first section concentrates on the general profile of the respondent including his/her age group, education level and profession and income group.

In the second section we were interested in finding the factors affecting the customer intention to use internet banking in Bahrain. The respondents were provided with a list of 10 questions; 4 questions on the perceived usefulness, 2 questions on the perceived ease of use, 3 questions on the perceived credibility and finally 1 question on the customer intention to use e-banking.

The participants were asked to indicate their perception on a likert scales (1-5) with response ranging from 
"strongly disagree" to "strongly agree". The collected data were analyzed based on correlation and regression analyses using the statistical package for social sciences (SPSS) version 17computer program.

\subsection{Data collection}

The questionnaires were distributed directly among the customers through the researchers' friends and relatives, a sample of 171 people was randomly chosen from the Bahraini community, all participants were bank customers selected randomly from universities, malls, Internet cafés and businessmen from private and public sectors.

Also A digital online form was created using "Google Documents" in the same questionnaire style, and then the link was shared and publicized to Bahraini's through email as well as posting it on discussion forums. Once a subject would answer the questionnaire, the raw data will automatically be logged in a spreadsheet which can be only accessed and downloaded by the researcher.

Since the questionnaire form was to be submitted online it guaranteed two things: First, it targeted people who really access the internet. Second, because all questions are need to be answered before submitting. The collection of data will be done automatically, efficiently and there won't be any loss of data

The questionnaire we prepared and used had been pre-tested initially with a few number of people (5 users) working in different sectors to ensure consistency, clarity and relevance to the Bahraini case, Minor changes (related to the questions content, wording, sequence) were requested by those people, which we implemented before carrying out the final copy.

A total of 171 useable responses were obtained.

[Insert table 1 here]

\section{Research model and hypotheses}

The model of the study is presented below:

[Insert figure 2 here]

The representation of the proposed framework depicted the pattern and structure of relationships between the set of the measured variables.

The purpose of the study is to measure correlations among variables and then use it to identify whether any relationships exists between these measured variables or not.

We will extended TAM and add PC into the framework to test the effect of these three factors on e-banking adaption.

The present study will investigate the relationship between perceived usefulness (PU), perceived ease of use (PEOU), perceived credibility (PC) and customer intention to use electronic banking in Bahrain. The (PU), (PEOU) and (PC) were being considered as independent variables and the customer intention to use electronic banking was being considered as a dependent variable.

\subsection{Perceived usefulness}

According to Davis et al. (1989), perceived usefulness is "the degree to which a person believes that using a particular system would enhance his or her job performance". Also Perceived usefulness is defined as "the individual's perception that using the new technology will enhance or improve her/his performance" (Davis, 1993).

In Addition, Laforet and Li, (2005) and Eriksson et al., (2005) defined the term perceived usefulness as "the subjective probability that using the technology would improve the way a user could complete a given task".

We hypothesize that People tend to use an application to the extent they believe it will aid their performance.

H1: Perceived usefulness (PU) has a positive effect on customer Intention to use Electronic banking.

\subsection{Perceived ease of use}

According to Davis (1989) perceived ease of use refers to "the degree to which a person believes that using a particular system would be free of effort".

Hence an application perceived to be easier to use than another is more likely to be accepted by users. And By applying these to the electronic banking context we can hypothesize that:

H2: Perceived ease of use (PEOU) has a positive effect on customer Intention to use Electronic banking. 


\subsection{Perceived credibility}

Perceived credibility is defined as "the degree to which a user feels the certainty and pleasant consequences of using an electronic application service, when there is no financial risk, physical risk, functional risk, social risk, time-loss risk, opportunity cost risk, and information risk" Jacoby and Kaplan (1972).

However, (Ganesan, 1994) present another definition of (PC) stating it as "the extent to which one partner believes that the other partner has the required expertise to perform the job effectively and reliably".

Wang et al. (2003) stated that perceived credibility is consists of two important elements namely privacy and security, which affect directly consumer adaptation of electronic banking systems.

Security refers to the protection of information or systems from unauthorized intrusions (Egwali, 2008). For the purpose of this research, "perceived credibility" (PC) is defined as users' perception of protection of their transaction details and personal data against unauthorized access.

Therefore, for studying the effect of perceived credibility on user's acceptance in Bahrain electronic banking services, we pose the following hypothesis to determine its effect on user's intention.

H3: perceived credibility has positive effect on customer Intention to use electronic banking.

\section{Result analysis}

\subsection{Regression analysis}

1). Simple regression with Intention as the dependent variable and usefulness as the independent variable

\section{[Insert table 2, 3, and 4 here]}

Based on $(\mathrm{F}>1.9 \& \mathrm{Siq}<0.005)$ we will accept $\mathrm{H}_{1}$ and Reject $\mathrm{H}_{0}$.

Interpretation:

If there is no usefulness, i.e. usefulness is equal to zero, the level of Intention is $=.490$.

The $\%$ of change on intention as a result of one unit change in usefulness, i.e. slope, is equal to .840 .

2). Simple regression with Intention as the dependent variable and ease of use as the independent variable

[Insert table 5, 6, 7 and 8 here]

Based on $(\mathrm{F}>1.9 \& \mathrm{Siq}<0.005)$ we will accept $\mathrm{H} 1$ and Reject H0.

Interpretation:

If there is no ease of use, i.e. ease of use is equal to zero, the level of Intention is $=1.154$.

The $\%$ of change on intention as a result of one unit change in ease of use, i.e. slope, is equal to 693 .

3). Simple regression with Intention as the dependent variable and Credibility as the independent variable

[Insert table 9, 10, 11, and 12 here]

Based on $(\mathrm{F}>1.9 \& \mathrm{Siq}<0.005)$ we will accept $\mathrm{H} 1$ and Reject H0.

Interpretation:

If there is no credibility, i.e. credibility is equal to zero, the level of Intention is $=2.207$.

The $\%$ of change on intention as a result of one unit change in credibility, i.e. slope, is equal to .589 .

\section{Discussion}

According to the previous tables it's clear that most respondents agree with the idea that said "internet banking is useful" it can be seen that more than $80 \%$ of them at least agreed with it. This result is also can be driven from the calculated mean from one-sample test which equal to 3.9678 with $t=17.436$, which is Consistent with most of the previous literatures that consider perceived usefulness as a source of satisfaction with internet banking. The respondents answers in the questionnaire show that most of them consider Internet banking as an alternative for going to the bank and useful to conduct their banking activities more quickly, which support the seven factors model preformed by Sadeghi and Hanzaee (2010).

Furthermore by referring to the simple regression between (PU) and the intention to use e-banking and discussing the resulting figures ( $\mathrm{sig}=0<0.05, \mathrm{f}=101.4>1.9$ ) which mean that there is strong positive correlation between the (PU) and the customer Acceptance of e-banking and that is confirming our first hypothesis $\mathrm{H} 1$ so it's now accepted that "Perceived usefulness (PU) has a positive effect on customer Intention to use Electronic banking" which is identically the same conclusion of Jahangir N. and Begum N. (2008) and Safeena et al. (2009) 
who consider (PU) as one of three important determinants of online banking adoption with a positive effect .

Approximately the same customers also consider e-banking as an ease to use Application and they can achieve their banking transactions via the internet, According to the one-sample statistics the mean is 3.8538 and $\mathrm{t}=13.890$, it can be noticed that (PEOU) and (PU) both has a positive impact on the customer satisfaction which may support the past results of Al-Somali et al. (2009) about the significant effects of this factors.

Moreover the simple regression between this factor as an independent variable and the intention to use e-banking as a dependent variable shows appositive strong correlation ( $\operatorname{sig}=0<0.05, \mathrm{f}=76.841>1.9$ ) which is clearly lead to the existence of our assumed relationship in the second hypothesis $\mathrm{H} 2$ so we accept it and conclude that "Perceived ease of use (PEOU) has a positive effect on customer Intention to use Electronic banking" as a Confirmation to the findings of Z Liao and WK Wong (2008) who study and investigate the same factors and get the same observations about the positive and significant influence of the perceived ease of use on the customer acceptance.

On the other hand, when we come to discuss the credibility factors (security \& privacy) we get the opposite results because more than $80 \%$ of the respondents do not trust on the level of security and privacy offered by the e-banking systems and do not feel safe when they achieve their banking transactions or release their credit card information through the Internet. It's clear from the one-sample statistics test that the credibility factors are one of the most important sources of customer's dissatisfaction.

The calculated mean is 2.7466 which is less than the average of likert-scale levels, furthermore these results confirm the previous conclusions of Alda's-Manzano et al. (2009) who focused on the credibility variables and considered Trust as a key variable that reduces perceived risk.

In addition when we see the regression between the credibility and the customer intention to use e-banking it can be noticed that there is a negative effect by the risk factors ( $\mathrm{sig}=0<0.05, \mathrm{f}=64.035>1.9)$ which means that the customers who do not trust on credibility level of e-banking systems do not intend to use or continue using it, this conclusion is identical to that of Aderonke and Charles (2010) who found that the security and privacy of the system are the major concerns of the users. And that confirm our third hypothesis so we accept $\mathrm{H} 3$ which state that "perceived credibility has positive effect on customer Intention to use Electronic banking".

\section{Conclusion \& recommendations}

The statistical analysis results show that the perceived usefulness, perceived ease of use and perceived credibility are the main important determinants of internet banking adoption, all these three factors have a great influence on the customers acceptance of the system.

Moreover, the system credibility disturb both the current and potential customers who intended to use internet banking services, because of the risk that their personal information might fall into wrong hands or may lose their money during the transaction process.

For this research, the following limitations existed in the collection and analyzing data. First the survey assumed that the respondents have the same level of internet skills, familiarity with banks and banking transactions and have been exposed to or have knowledge of the existence of e-banking alternatives. For these responses in particular, it was difficult to ensure the true validity of the responses or the identity of the respondent. Second the sample size was relatively small and most respondents were young. Third a linear regression (between the variables) is used instead of multiple regressions and no correlation test was made between demographics and the main three factors.

Finally, from our study we present the following suggestions:

1) Future study might involve testing the effects of other external factors such as service quality, speed and Computer Self-Efficacy on our considered factors (PU, PEOU and PC). And the affects of the same factors on internet banking adoption.

2) Banks need to offer knowledge to their customers about transactions security and privacy to increase the trust of using the web system.

3) Internet banking is gaining more popularity and becoming important in doing financial transactions, so Bank's mangers have to improve their services to attract more customers.

4) Customers point view and their suggestions should be considered in any future survey. 


\section{References}

Aderonke, and Charles. (2010). An Empirical Investigation of the Level of Users' Acceptance of E-Banking in Nigeria. Journal of Internet Banking and Commerce, Vol. 15 (1).

Al Nahian Riyadh, Md. Shahriar Akter, Nayeema Islam. (2009). The adoption of e-banking in developing countries: A theoretical model for SMEs. International Review of Business Research Papers, 5 (6), 212-230.

Al-Somali, S.A., Gholami, R., and Clegg, B.(2009). An investigation into the acceptance of online banking in Saudi Arabia. Technovation, 29, 130-141. doi:10.1016/j.technovation.2008.07.004, http://dx.doi.org/10.1016/j.technovation.2008.07.004

Ba, S., and Pavlou, P.A. (2002). Evidence of the effect of trust building technology in electronic market: price premiums and buyer behavior.MIS Quarterly, 26 (3), 243-68. doi:10.2307/4132332, http://dx.doi.org/10.2307/4132332

Celik, H. (2008). What Determines Turkish customers' acceptance of internet banking? International Journal of Bank Marketing. $26 \quad$ (5), 353-370. doi:10.1108/02652320810894406, http://dx.doi.org/10.1108/02652320810894406

Chen, Y. H., and Barnes, S. (2007). Initial Trust and Online Buyer Behavior. Industrial Management \& Data Systems, 107(1), 21-36. doi:10.1108/02635570710719034, http://dx.doi.org/10.1108/02635570710719034

Davis, F. D. (1989). Perceived Usefulness, Perceived Ease of Use, and User Acceptance of Information Technology. MIS Quarterly, 13(3), 319-339. doi:10.2307/249008, http://dx.doi.org/10.2307/249008

Davis, F. D. (1993). User acceptance of information technology: system characteristics, user perceptions and behavioral impacts. International Journal of Man-Machine Studies, 38, 475-487. doi:10.1006/imms.1993.1022, http://dx.doi.org/10.1006/imms.1993.1022

Davis, F. D., Bagozzi, R. P., \& Warshaw, P. R. (1992). Extrinsic and intrinsic motivation to use computers in the workplace. Journal of Applied Social Psychology, 22(14), 1109-1130. doi:10.1111/j.1559-1816.1992.tb00945.x, http://dx.doi.org/10.1111/j.1559-1816.1992.tb00945.x

Davis, F. D., Bagozzi, R. P., and Warshaw, P. R. (1989). User Acceptance of Computer Technology: A Comparison of Two Theoretical Models. Management Science, 35(8), 982-1003. doi:10.1287/mnsc.35.8.982, http://dx.doi.org/10.1287/mnsc.35.8.982

Egwali, A. O. (2008). Customer Perception of Security Indicators in Online Banking Sites in Nigeria. Journal of Internet Banking and Commerce, 13(3).

Eriksson K., Kerem K., \& Nilsson D. (2005). Customer acceptance of internet banking in Estonia. International Journal of Bank Market, 23 (2), 200-216. doi:10.1108/02652320510584412, http://dx.doi.org/10.1108/02652320510584412

Ganesan, S. (1994). Determinants of long-term orientation in buyer-seller relationships. Journal of Marketing, 58 (2), 1-19. doi:10.2307/1252265, http://dx.doi.org/10.2307/1252265

Hanudin Amin (2007). Internet Banking Adoption Among Young Intellectuals. Journal of Internet Banking and Commerce, 12 (3).

Jacoby, J., \& Kaplan, L. B. (1972). The components of perceived risk. Paper presented at the Proceedings of the 3rd Annual Conference of the Association for Consumer Research, College Park, MD.

Joaquin Alda's-Manzano, Carlos Lassala-Navarre, Carla Ruiz-Mafe, and Silvia Sanz-Blas. (2009). Key drivers of internet banking services use . Online Information Review, 33 (4), 672-695. doi:10.1108/14684520910985675, http://dx.doi.org/10.1108/14684520910985675

Laforet S, Li X (2005). Consumers' attitudes towards online and mobile banking in China. International Journal Bank Market, 23(5), 362-380. doi:10.1108/02652320510629250, http://dx.doi.org/10.1108/02652320510629250

Liao, Z., \& Wong, W. K. (2008). The determinants of customer interactions with internet-enabled e-banking services. Journal of the Operational Research Society, 59(9), 1201-10. doi:10.1057/palgrave.jors.2602429, http://dx.doi.org/10.1057/palgrave.jors.2602429

Moutaz Abou-Robieh (2005). A Study of E-Banking Security Perceptions and Customer Satisfaction Issues.

Nadim Jahangir, and Noorjahan Begum (2008). The role of perceived usefulness, perceived ease of use, security and privacy, and customer attitude to engender customer adaptation in the context of electronic banking. African Journal of Business Management, 2(1), 032-040. 
Padachi, Rojid, \& Seetanah (2007). Analyzing the Factors that Influence the Adoption of Internet Banking in Mauritius.

Patrick, T. (2002). Corporate Privacy Credibility Crumbles. Computer world, March, 4(10).

Pikkarainen, T., Pikkarainen, K., Karijaluoto, H., and Pahnila, S. (2004). Customer acceptance of on-line banking: an extension of the technology acceptance model. Internet Research, 14(3), 224-235. doi:10.1108/10662240410542652, http://dx.doi.org/10.1108/10662240410542652

Qureshi, T.M., Zafar, M.K., and Khan, M.B. (2008). Customer Acceptance of Online Banking in Developing Economies. Journal of Internet Banking and Commerce, Vol. 13 (1).

Safeena, Abdullah and Hema. (2010). Customer Perspectives on E-business Value: Case Study on Internet Banking. Journal of Internet Banking and Commerce, 15 (1).

Seth, N., S.G. Deshmukh, and P. Vrat (2004). Service quality models: A review. International Journal Quality and Reliability Management, 22(9), 36-51.

T.C. Edwin Cheng, David Y.C. Lam, and Andy C.L. Yeung (2006). Adoption of internet banking: An empirical study in Hong Kong. Decision Support Systems, 42 (3), 1558-1572. doi:10.1016/j.dss.2006.01.002, http://dx.doi.org/10.1016/j.dss.2006.01.002

Tooraj Sadeghi, and Kambiz Heidarzadeh Hanzaee (2010). Customer satisfaction factors (CSFs) with online banking services in an Islamic country I.R. Iran. Journal of Islamic Marketing, 1(3), 249-267. doi:10.1108/17590831011082428, http://dx.doi.org/10.1108/17590831011082428

Wai-Ching Poon (2008). Users' adoption of e-banking services. Journal of Business \& Industrial Marketing, 23(1), 59-69. doi:10.1108/08858620810841498, http://dx.doi.org/ 10.1108/08858620810841498

Wang, Y., Lin, H., \& Tang, T. (2003). Determinants of user acceptance of internet banking: an empirical study. International Journal of Service Industry Management, 14(5), 501-519. doi:10.1108/09564230310500192, http://dx.doi.org/10.1108/09564230310500192

Yap, K., D. Wong, C. Loh, and R. Bak (2010). Offline and online banking - where to draw the line when building trust in e-banking. International Journal of Bank Marketing, 28(1), 27-46. doi:10.1108/02652321011013571, http://dx.doi.org/10.1108/02652321011013571

Table 1. Demographic profile of respondents

\begin{tabular}{|l|l|l|l|}
\hline Variable & Category & Frequency & Valid Percentage \\
\hline \multirow{5}{*}{ Age } & $18-25$ & 86 & $50.3 \%$ \\
& $25-35$ & 60 & $53.1 \%$ \\
& $35-45$ & 14 & $8.2 \%$ \\
& 45 yrs and above & 11 & $6.4 \%$ \\
\hline \multirow{5}{*}{ Gender } & Male & 87 & $50.9 \%$ \\
& Female & 84 & $49.1 \%$ \\
\hline \multirow{5}{*}{ Occupation } & Secondary and below & 22 & $12.9 \%$ \\
& Diploma & 41 & $24 \%$ \\
& Bachelor & 90 & $52.6 \%$ \\
& High studies & 18 & $10.5 \%$ \\
\hline \multirow{3}{*}{ Monthly Income in BD } & Government sector & 59 & $34.5 \%$ \\
& Private Sector & 48 & $28.1 \%$ \\
& Self-employment & 13 & $7.6 \%$ \\
& Others & 51 & $29.8 \%$ \\
\hline & Less than 500 & 101 & $59.1 \%$ \\
& $500-1000$ & 59 & $34.5 \%$ \\
\hline
\end{tabular}


Table 2. Variables Entered/Removed ${ }^{\mathrm{b}}$

\begin{tabular}{|c|c|c|c|}
\hline Model & Variables Entered $^{\text {Variables Removed }}$ & Method \\
\hline 1 & Usefulness $^{\text {a }}$ &. & Enter \\
\hline
\end{tabular}

a. All requested variables entered.

b. Dependent Variable: I intend to use (or continue using) Internet banking in the future.

Table 3. Model Summary

\begin{tabular}{|c|c|c|c|c|}
\hline Model & R & R Square & Adjusted R Square & Std. Error of the Estimate \\
\hline 1 & $.612^{\mathrm{a}}$ & .375 & .371 & .790 \\
\hline
\end{tabular}

a. Predictors: (Constant), usefulness

Table 4. ANOVA ${ }^{\mathrm{b}}$

\begin{tabular}{|c|c|c|c|c|c|c|}
\hline \multicolumn{2}{|c|}{ Model } & Sum of Squares & df & Mean Square & F & Sig. \\
\hline 1 & Regression & 63.276 & 1 & 63.276 & 101.400 & $.000 \mathrm{a}$ \\
\hline & Residual & 105.461 & 169 & .624 & & \\
\hline & Total & 168.737 & 170 & & & \\
\hline
\end{tabular}

a. Predictors: (Constant), usefulness

b. Dependent Variable: I intend to use (or continue using) Internet banking in the future.

Table 5. Coefficients ${ }^{\mathrm{a}}$

\begin{tabular}{|c|c|c|c|c|c|c|}
\hline \multirow{2}{*}{\multicolumn{2}{|c|}{ Model }} & \multicolumn{2}{|c|}{$\begin{array}{c}\text { Standardized } \\
\text { Coefficients }\end{array}$} & \multirow{2}{*}{ Sig. } \\
\cline { 2 - 7 } & Unstandardized Coefficients & B & Std. Error & Beta & $\mathrm{t}$ & .148 \\
\hline \multirow{2}{*}{1} & (Constant) & .490 & .337 & & 1.454 & .000 \\
\cline { 2 - 7 } & usefulness & .840 & .083 & .612 & 10.070 & .000 \\
\hline
\end{tabular}

a. Dependent Variable: I intend to use (or continue using) Internet banking in the future.

Table 6. Variables Entered/Removed ${ }^{\text {b }}$

\begin{tabular}{|c|c|c|c|}
\hline Model & Variables Entered & Variables Removed & Method \\
\hline 1 & Ease of usea &. & Enter \\
\hline
\end{tabular}

a. All requested variables entered.

b. Dependent Variable: I intend to use (or continue using) Internet banking in the future.

Table 7. Model Summary

\begin{tabular}{|c|c|c|c|c|}
\hline Model & R & R Square & Adjusted R Square & Std. Error of the Estimate \\
\hline 1 & $.559 \mathrm{a}$ & .313 & .308 & .828 \\
\hline
\end{tabular}

a. Predictors: (Constant), ease of use

Table 8. ANOVA ${ }^{\mathrm{b}}$

\begin{tabular}{|c|c|c|c|c|c|c|}
\hline \multicolumn{2}{|c|}{ Model } & Sum of Squares & df & Mean Square & F & Sig. \\
\hline 1 & Regression & 52.741 & 1 & 52.741 & 76.841 & $.000 \mathrm{a}$ \\
\hline & Residual & 115.996 & 169 & .686 & & \\
\hline & Total & 168.737 & 170 & & & \\
\hline
\end{tabular}

a. Predictors: (Constant), ease of use

b. Dependent Variable: I intend to use (or continue using) Internet banking in the future. 
Table 9. Coefficients ${ }^{\mathrm{a}}$

\begin{tabular}{|c|c|c|c|c|c|}
\hline \multicolumn{2}{|c|}{ Model } & $\begin{array}{c}\text { Unstandardized } \\
\text { Coefficients }\end{array}$ & $\begin{array}{c}\text { Standardized } \\
\text { Coefficients }\end{array}$ & $\mathrm{t}$ & Sig. \\
\hline & B & Std. Error & Beta & & \\
\hline 1 & (Constant) & 1.154 & .311 & & 1 \\
\hline & Ease of use & .693 & .079 & .559 & \\
\hline
\end{tabular}

a. Dependent Variable: I intend to use (or continue using) Internet banking in the future.

Table 10. Variables Entered/Removed ${ }^{\text {b }}$

\begin{tabular}{|c|c|c|c|}
\hline Model & Variables Entered & Variables Removed & Method \\
\hline 1 & Credibilitya &. & Enter \\
\hline
\end{tabular}

a. All requested variables entered.

b. Dependent Variable: I intend to use (or continue using) Internet banking in the future.

Table 11. Model Summary

\begin{tabular}{|c|c|c|c|c|}
\hline Model & $\mathrm{R}$ & R Square & Adjusted R Square & Std. Error of the Estimate \\
\hline 1 & $.524 \mathrm{a}$ & .275 & .270 & .851 \\
\hline
\end{tabular}

a. Predictors: (Constant), Credibility

Table 12. ANOVA ${ }^{\mathrm{b}}$

\begin{tabular}{|c|c|c|c|c|c|c|}
\hline \multicolumn{2}{|c|}{ Model } & Sum of Squares & $\mathrm{df}$ & Mean Square & $\mathrm{F}$ & Sig. \\
\hline 1 & Regression & 52.741 & 1 & 46.367 & 64.035 & $.000 \mathrm{a}$ \\
\hline & Residual & 115.996 & 169 & .724 & & \\
\hline & Total & 168.737 & 170 & & & \\
\hline
\end{tabular}

a. Predictors: (Constant), Credibility

b. Dependent Variable: I intend to use (or continue using) Internet banking in the future.

Table 13. Coefficients ${ }^{\mathrm{a}}$

\begin{tabular}{|c|c|c|c|c|c|c|}
\hline \multirow{2}{*}{\multicolumn{2}{|c|}{ Model }} & \multicolumn{2}{|c|}{ Unstandardized Coefficients } & \multirow{2}{*}{$\begin{array}{c}\begin{array}{c}\text { Standardized } \\
\text { Coefficients }\end{array} \\
\text { Beta }\end{array}$} & \multirow[b]{2}{*}{$\mathrm{t}$} & \multirow[b]{2}{*}{ Sig. } \\
\hline & & $\mathrm{B}$ & Std. Error & & & \\
\hline \multirow[t]{2}{*}{1} & (Constant) & 2.207 & .212 & & 10.393 & .000 \\
\hline & Credibility & .589 & .074 & .524 & 8.002 & .000 \\
\hline
\end{tabular}

a. Dependent Variable: I intend to use (or continue using) Internet banking in the future 


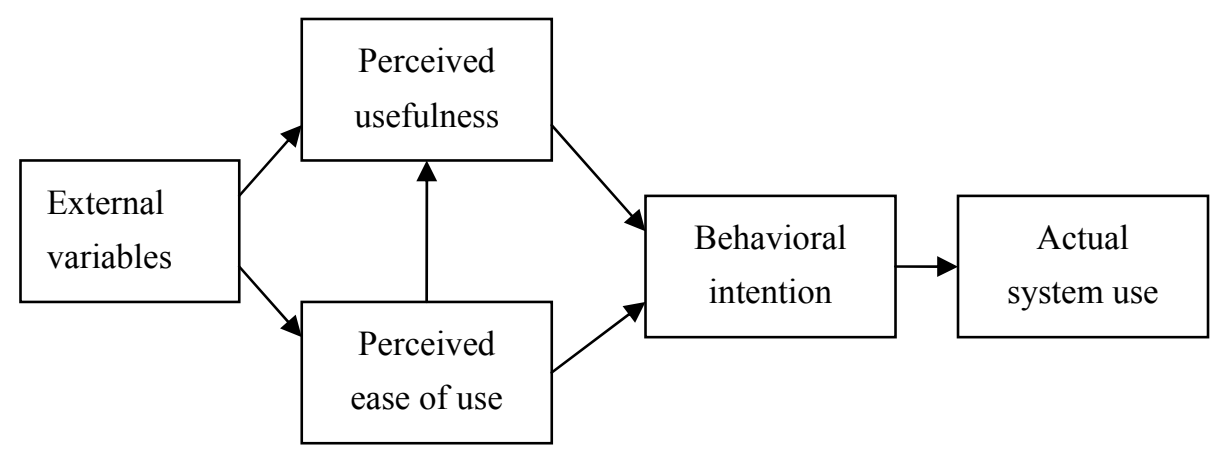

Figure 1. The original Technology Acceptance Model (Davis, 1989)

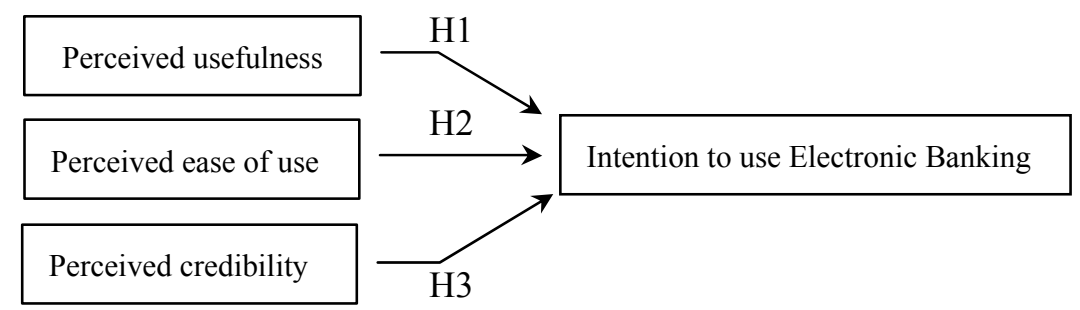

Figure 2. Research Model 